\title{
PENGUJIAN PUPUK ORGANIK GRANUL TERHADAP PADI SAWAH VARIETAS UNGGUL BARU
}

\author{
Helmi $^{(1)}$, Ilyas ${ }^{(1)}$ dan Bakhtiar Basyah ${ }^{(2)}$ \\ ${ }^{1)}$ Prodi Ilmu Tanah Fakultas Pertanian Unsyiah \\ ${ }^{2)}$ Prodi Agroteknologi Fakultas Pertanian Unsyiah \\ Coresponden Email: helmi@unsyiah.ac.id
}

\begin{abstract}
ABSTRAK
Petani cenderung menggunakan pupuk an-organik terus-menerus sehingga menyebabkan kerusakan tanah dan produksi padi terganggu. Penelitian ini bertujuan untuk mengurangi ketergantungan penggunaan pupuk kimia an-organik sehingga dapat menutupi kekurangan penyediaan pupuk kimia an-ornanik dengan pupuk organik, meningkatkan produksi tanaman dan secara ekonomi menguntungkan dan mengurangi biaya produksi usaha tani padi sawah. Penelitian ini menggunakan Rancangan Acak Kelompok (RAK) faktorial dengan 3 ulangan. Ada 2 faktor yang perlakuan yang dikaji yaitu varietas padi dan dosis pupuk organik granul. Pemberian pupuk organik granul berpengaruh nyata terhadap pertumbuhan dan hasil tanaman padi yaitu tinggi tanaman, persentase gabah bernas per malai, bobot 1000 butir gabah dan produksi per hektar baik pada varietas Mekongga maupun varietas Inpari 16. Dosis pemberian pupuk organik granul yang memberikan hasil tertinggi untuk tanaman padi varietas Mekongga dan Inpari 16 adalah 2,0 ton/ha.
\end{abstract}

Keywords: pupuk; organik; granul; padi; varietas.

\section{PENDAHULUAN}

Pemerintah Indonesia mulai mengubah sistem pertanian yang selama ini pertanian modern yang berlandaskan pada penggunaan pupuk an-organik dan pestisida menjadi pertanian organik yang berlandaskan pada penggunaan pupuk organik dan proteksi organik. Upaya perubahan sistem pertanian ini tidak semudah membalikkan telapak tangan. Salah satu upaya yang dilakukan untuk merubah sistem pertanian tersebut adalah melalui penyuluhan dan bertahap mulai dari mengurangi penggunaannya sampai tidak menggunakan lagi.

Penelitian demplot pemberian pupuk organik granul pada budidaya padi sawah varietas Mekongga dan Inpari 16 di Desa Jurong Pantee Kecamatan Sakti dan Desa Mesjid Ilot Kecamatan Mila Kabupaten Pidie. Lokasi tersebut dipilih dengan pertimbangan bahwa di desa tersebut merupakan desa yang memiliki lahan sawah dengan komoditas padi dipinggir jalan besar sehingga demplot mudah dilihat orang.
Menurut petugas pertanian diwilayah tersebut kebanyakan dari petani menggunaan pupuk kimia an-organik terus menerus dalam budidaya tanaman mereka sehingga terjadi penurunan produktivitas tanah. Dari lahan percontohan tersebut, dapat diketahui bagaimana penerapan suatu inovasi khusus. Dalam hal ini inovasi khusus tersebut berupa pemberian pupuk organik pada tanaman padi.

Pupuk organik mempunyai peranan yang menyeluruh dalam tanah. Untuk mengembalikan kesuburan tanah, penggunan pupuk an-organik harus diimbangi dengan penggunaan pupuk organik. Selain sebagai suplai hara bagi tanaman, pupuk organik juga dapat memperbaiki struktur tanah, sifat fisik dan kimia tanah sehingga dapat membantu pelestarian kesuburan tanah dan ramah lingkungan. Tujuan pemberian pupuk organik granul pada padi sawah untuk mengurangi ketergantungan penggunaan pupuk kimia an-organik sehingga dapat menutupi kekurangan penyediaan pupuk 
kimia an-ornanik dengan pupuk organik, meningkatkan produksi tanaman dan secara ekonomi menguntungkan dan mengurangi biaya produksi usaha tani padi sawah.

\section{METODE PENELITIAN}

Penelitian ini dilaksanakan di dua lokasi persawahan di Kabupaten Pidie yaitu di Desa Jurong Pantee Kecamatan Sakti dan Desa Mesjid Ilot Kecamatan Mila. Pelaksanaan dilakukan pada bulan April sampai September 2019. Penelitian ini menggunakan Rancangan Acak Kelompok (RAK) faktorial dengan 3 ulangan. Ada 2 faktor yang perlakuan yang dikaji yaitu varietas padi dan dosis pupuk organik granul.

Bibit padi yang dicobakan adalah bibit padi varietas Mekongga dan Inpari 16. Sumber bahan pupuk organik granul diperoleh dari kios penjual pupuk organik granul yang ada di Wilayah Kecamatan Sakti dan Kecamatan Mila Kabupaten Pidie. Perlakuan varietas terdiri 2 taraf sebagai

berikut:

$\mathrm{V}_{1}=$ Mekongga dan

$\mathrm{V}_{2}=$ Inpari 16

Perlakuan pupuk organik granul terdiri 5 taraf sebagai berikut:

$\mathrm{P}_{0}=0 \mathrm{Ton} / \mathrm{Ha}=0 \mathrm{Kg} / \mathrm{m} 2=0 \mathrm{Kg} / \mathrm{Plot}$

$\mathrm{P}_{1}=0,5 \mathrm{Ton} / \mathrm{Ha}=0,05 \mathrm{Kg} / \mathrm{m} 2=25 \mathrm{Kg} / \mathrm{Plot}$

$\mathrm{P}_{2}=1 \mathrm{Ton} / \mathrm{Ha}=0,10 \mathrm{Kg} / \mathrm{m} 2=50 \mathrm{Kg} / \mathrm{Plot}$

$\mathrm{P}_{3}=1,5 \mathrm{Ton} / \mathrm{Ha}=0,15 \mathrm{Kg} / \mathrm{m} 2=75$

$\mathrm{Kg} / \mathrm{Plot}$

$\mathrm{P}_{4}=2.0 \mathrm{Ton} / \mathrm{Ha}=0,20 \mathrm{Kg} / \mathrm{m} 2=100$

$\mathrm{Kg} / \mathrm{Plot}$

\section{HASIL DAN PEMBAHASAN Pertumbuhan Tanaman}

Berdasarkan uji $\mathrm{F}$ sidik ragam pada taraf $5 \%$, rata-rata tinggi tanaman pada umur 60 Hari Setelah tanam (HST) tidak berbeda nyata akibat perlakuan dosis pupuk organik granul pada varietas Mekongga di Kecamatan Sakti, sedangkan pada varietas Mekongga di Kecamatan Mila serta varietas Inpari 16 baik di Kecamatan Sakti maupun dikecamatan Mila berbeda nyata. Tabel 1 menunjukkan bawa semakin tinggi dosis pupuk organik granul yang diberikan tanaman menjadi lebih tinggi, terutama pada varietas Inpari 16. Hal tersebut menunjukan bahwa semua perlakuan pupuk organik granul dapat mendorong pertumbuhan tinggi tanaman yang lebih tinggi karena bahan organik mengandung banyak unsur Carbon. Carbon merupakan komponen paling besar dalam bahan organik sehingga pemberian bahan organik akan meningkatkan kandungan carbon tanah. Tubuh tanaman tersusun dari karbon, sehingga pembentukan tinggi tanaman sangat dipengaruhi unsur $\mathrm{C}$ dan N. Bahan organik buatan memiliki beberapa fungsi selain meningkatkan kandungan unsur hara, yaitu menggemburkan tanah serta merangsang pertumbuhan tanaman (Rao, 2002).

Tabel 1. Rata-Rata Tinggi Tanaman Padi Pada Umur 60 HST Akibat Pemberian Pupuk Organik Granul pada Varietas Mekongga dan Inpari 16 di Kecamatan Sakti dan Kecamatan Mila

\begin{tabular}{|l|c|c|c|c|}
\hline \multirow{4}{*}{ Perlakuan } & \multicolumn{3}{|c|}{ Tinggi Tanaman $(\mathrm{cm})$} \\
\cline { 2 - 5 } & \multicolumn{2}{|c|}{$\begin{array}{c}\text { Varietas } \\
\text { Mekongga }\left(\mathrm{V}_{1}\right)\end{array}$} & \multicolumn{2}{c|}{$\left.\begin{array}{c}\text { Varietas Inpari } \\
16\end{array} \mathrm{~V}_{2}\right)$} \\
\cline { 2 - 5 } & SAKTI & MILA & SAKTI & MILA \\
\hline $\mathrm{P}_{0}$ & 90 & $90 \mathrm{a}$ & $90 \mathrm{a}$ & $89 \mathrm{a}$ \\
\hline $\mathrm{P}_{1}$ & 92 & $94 \mathrm{a}$ & $92 \mathrm{abc}$ & $91 \mathrm{a}$ \\
\hline $\mathrm{P}_{2}$ & 93 & $103 \mathrm{~b}$ & $94 \mathrm{bc}$ & $95 \mathrm{~b}$ \\
\hline $\mathrm{P}_{3}$ & 91 & $105 \mathrm{~b}$ & $98 \mathrm{~d}$ & $98 \mathrm{~b}$ \\
\hline $\mathrm{P}_{4}$ & 104 & $108 \mathrm{~b}$ & $105 \mathrm{e}$ & $104 \mathrm{c}$ \\
\hline Rata-Rata & & & & \\
& 94,0 & 100,0 & 95,8 & 95,2 \\
\hline BNT0,05 & - & 5,22 & 2,45 & 3,52 \\
\hline
\end{tabular}

Keterangan: Angka-angka yang diikuti oleh huruf yang sama pada kolom yang sama, tidak berbeda nyata pada taraf BNT 0,05

Tinggi tanaman diamati dan diukur untuk mengetahui pertumbuhan vegetatif pada suatu tanaman. Pertumbuhan dan perkembangan tanaman merupakan proses yang penting dalam kehidupan dan perkembangbiakan suatu varietas. Pertumbuhan tanaman yang baik dipengaruhi oleh faktor dalam dan faktor luar tanaman itu sendiri (Sitompul dan Guritno, 1995). Faktor lingkungan yang mempengaruhi tanaman diantaranya adalah 
ketersediaan air, unsur hara, iklim dan adanya hama dan penyakit (Gardner, et al. 1991). Tanaman selama hidupnya menghasilkan biomassa yang digunakan untuk membentuk bagian-bagian tubuhnya yang terjadi seiring dengan umur tanaman. Biomassa yang dihasilkan oleh tanaman sangat dipengaruhi oleh baik tidaknya pertumbuhan vegetatif maka akan semakin besar pula biomassa yang dihasilkan.

Lebih lanjut Ponnam peruma (1984) menerangkan bahan organik dari pupuk organik berguna sebagai bahan pensuplai berbagai unsur hara $(\mathrm{C}, \mathrm{N}, \mathrm{P}, \mathrm{K}, \mathrm{S}$, dan senyawa lainnya) dalam kisaran yang luas sebagai hasil dari proses dekomposisi berupa senyawa sederhana yang cepat dimanfaatkan oleh mikroorganisme tanah dan juga tersedia sebagai hara bagi tanaman diantaranya nitrogen sehingga ketersediaan$\mathrm{N}$ tanah meningkat. Senyawa ini meliputi: karbohidrat, protein, asam amino, lemak, lilin, dan asam-asam organik dengan bobot atom ringan (Suprapto, 2002). Hadisuwito (2007) menyatakan bahwa fungsi unsur hara $\mathrm{N}$ yaitu membentuk protein dan klorofil, fungsi unsur $\mathrm{P}$ sebagai sumber energi yang membantu tanaman dalam perkembangan fase vegetatif salah satunya tinggi tanaman.

\section{Hasil Tanaman}

Rata-rata Persentase Gabah Bernas Per Malai, Bobot 1000 Butir Gabah dan Jumlah Produksi Per Hektar disajikan pada Tabel 2, Tabel 3 dan Tabel 4.

Tabel 2. Rata-Rata Persentase Gabah Bernas Tanaman Padi Akibat Pemberian Pupuk Organik Granul di Kecamatan Sakti dan Kecamatan Mila

\begin{tabular}{|l|c|c|c|c|}
\hline \multirow{4}{*}{ Perlakuan } & \multicolumn{3}{|c|}{ Persentase Gabah Bernas (\%) } \\
\cline { 2 - 5 } & $\left.\begin{array}{c}\text { Varietas } \\
\text { Mekongga (V }\end{array}\right)$ & \multicolumn{2}{c|}{$\begin{array}{c}\text { Varietas Inpari 16 } \\
\left(\mathrm{V}_{2}\right)\end{array}$} \\
\cline { 2 - 5 } & SAKTI & MILA & SAKTI & MILA \\
\hline $\mathrm{P}_{0}$ & 79 & 80 & $80 \mathrm{a}$ & 79 \\
\hline $\mathrm{P}_{1}$ & 80 & 80 & $81 \mathrm{ab}$ & 80 \\
\hline $\mathrm{P}_{2}$ & 81 & 81 & $82 \mathrm{abc}$ & 80 \\
\hline $\mathrm{P}_{3}$ & 81 & 81 & $83 \mathrm{bc}$ & 82 \\
\hline $\mathrm{P}_{4}$ & 82 & 82 & $84 \mathrm{c}$ & 84 \\
\hline Rata-Rata & 80,6 & 80,8 & 82,0 & 81,0 \\
\hline BNT0,05 & - & - & 2,15 & - \\
\hline
\end{tabular}

Keterangan: Angka-angka yang diikuti oleh huruf yang sama pada kolom yang sama, tidak berbeda nyata pada taraf BNT 0,05

Tabel di atas menunjukkan bahwa pemberian pupuk organik mampu meningkatkan gabah bernas dari $80 \%$ menjadi $84 \%$ pada varietas Inpari 16 di Kecamatan Sakti. Namun di Kecamatan Mila dan pada varietas Mekonggga di Kecamatan Sakti dan Mila tidak berbeda secara nyata yang berkisara $79 \%$ sampai 82 $\%$.

Tabel 3. Rata-Rata Bobot 1000 Butir Gabah Tanaman Padi Akibat Pemberian Pupuk Organik Granul di Kecamatan Sakti dan Kecamatan Mila

\begin{tabular}{|l|c|c|c|c|}
\hline \multirow{2}{*}{ Perlakuan } & \multicolumn{3}{|c|}{ Bobot 1000 Butir Gabah (g) } \\
\cline { 2 - 5 } & $\begin{array}{c}|c| \\
\text { Varietas } \\
\text { Mekongga }\left(\mathrm{V}_{1}\right)\end{array}$ & \multicolumn{2}{|c|}{$\begin{array}{c}\text { Varietas Inpari } 16 \\
\left(\mathrm{~V}_{2}\right)\end{array}$} \\
\cline { 2 - 5 } & SAKTI & MILA & SAKTI & MILA \\
\hline $\mathrm{P}_{0}$ & $21 \mathrm{a}$ & 22 & $23 \mathrm{a}$ & 24 \\
\hline $\mathrm{P}_{1}$ & $23 \mathrm{~b}$ & 24 & $24 \mathrm{ab}$ & 25 \\
\hline $\mathrm{P}_{2}$ & $24 \mathrm{bc}$ & 25 & $25 \mathrm{bc}$ & 27 \\
\hline $\mathrm{P}_{3}$ & $25 \mathrm{c}$ & 26 & $26 \mathrm{c}$ & 28 \\
\hline $\mathrm{P}_{4}$ & $27 \mathrm{~d}$ & 28 & $28 \mathrm{~d}$ & 30 \\
\hline $\begin{array}{l}\text { Rata- } \\
\text { Rata }\end{array}$ & 24 & 25 & 25,2 & 26,8 \\
\hline BNT0,05 & 1,03 & & 1,68 & \\
\hline
\end{tabular}

Keterangan: Angka-angka yang diikuti oleh huruf yang sama pada kolom yang sama, tidak berbeda nyata pada taraf BNT 0,05

Tabel 4. Rata-Rata Produksi Tanaman Padi Akibat Pemberian Pupuk Organik Granul di Kecamatan Sakti dan Kecamatan Mila

\begin{tabular}{|l|c|c|c|c|}
\hline \multirow{2}{*}{ Perlakuan } & \multicolumn{4}{|c|}{ Produksi (ton/ha) } \\
\cline { 2 - 5 } & $\begin{array}{c}\text { Varietas } \\
\text { Mekongga }\left(\mathrm{V}_{1}\right)\end{array}$ & $\begin{array}{c}\text { Varietas Inpari } \\
16 \\
\left(\mathrm{~V}_{2}\right)\end{array}$ \\
\cline { 2 - 5 } & SAKTI & MILA & SAKTI & MILA \\
\hline $\mathrm{P}_{0}$ & 5,20 & 5,15 & 5,71 & 5,60 \\
\hline $\mathrm{P}_{1}$ & 5,41 & 5,13 & 6,01 & 6,25 \\
\hline $\mathrm{P}_{2}$ & 5,60 & 5,74 & 6,22 & 6,42 \\
\hline $\mathrm{P}_{3}$ & 5,88 & 5,90 & 6,35 & 6,50 \\
\hline $\mathrm{P}_{4}$ & 6,25 & 6,30 & 6,81 & 6,75 \\
\hline Rata-Rata & 5,67 & 5,64 & 6,22 & 6,30 \\
\hline
\end{tabular}

Berdasarkan Hasil uji F sidik ragam menunjukkan bahwa berpengaruh nyata pada semua taraf dosis pemberian pupuk organik granul terhadap rata-rata persentase gabah bernas per malai, bobot 1000 butir 
gabah dan jumlah produksi per hektar. Hasil produksi per hektar merupakan tujuan utama dari budidaya tanaman padi. Pada penelitian ini, padi dipanen pada umur lebih kurang 110 hari setelah tanam (HST) serta ditandai dengan perubahan warna menjadi dari hijau ke kuning pada tanaman. Kejadian ini terjadi karena proses metabolisme tanaman berjalan dengan baik dan seragam. Unsur hara yang disuplai dari bahan organik dan penambahan pupuk NPK memberikan dampak yang hampir seragam pada setiap perlakuan. Selain itu, faktor lingkungan diduga juga berpengaruh terhadap hasil jumlah biji/malai, jumlah biji bernas, jumlah biji hampa dan bobot 1000 butir biji dimana ketiga parameter ini akan menentukan jumlah produksi per hektar. Dalam hal ini diduga kegiatan fotosintesa mempengaruhi nilai semua parameter, dimana nilai parameter tersebut tergantung kepada kegiatan tanaman selama fase reproduksi.

Fotosintesa yang terhambat membuat karbohidrat yang dihasilkan rendah. Menurut Harjadi (1988) bahwa karbohidrat yang meningkat maka dapat meningkatkan proses pertumbuhan sel dalam membentuk sel-sel baru, pembesaran sel-sel dan pembentukan jaringan tanaman. Panjang malai juga berpengaruh terhadap hasil biji/malai. Malai yang panjang akan mempengaruhi jumlah biji yang diperoleh, hal ini diperjelas oleh Tiur (2009), semakin panjang malai berpengaruh terhadap jumlah biji per malai. Jumlah biji yang terbentuk pada masing-masing malai menurut Bakhtiar et al., (2010) ditentukan oleh panjang malai dan jumlah cabang malai, dimana masing-masing akan menghasilkan biji. Hal tersebut menunjukan bahwa penggunaan pembenaman pupuk organik granul dan cacing tanah memberikan pengaruh yang hampir sama dengan penggunaan tanpa pemberian pupuk organik granul dan cacing tanah. Unsur hara yang terdapat pada bahan organik berupapupuk organik granul slow release sehingga akan memberikan pengaruh pada jangka panjang, hal tersebut berbeda dengan pupuk sintetis atau anorganik. Kelebihan pupuk anorganik dibanding pupuk organik diantaranya mampu memberikan efek yang lebih cepat dan memiliki bentuk fisik yang relatif lebih praktis dan menarik (Yunizar et al., 2012). Jumlah bobot biji/malai dipengaruhi oleh unsur $\mathrm{N}$ dan unsur P. Kekurangan unsur $\mathrm{N}$ akan mengakibatkan biji dalam gabah tidak terisi. Tanaman padi yang kekurangan nitrogen, sedikit anakannya dan pertumbuhannya kerdil. Daunnya berwarna hijau muda kekuning-kuningan serta menyebabkan butir pada malai banyak yang hampa (Siregar, 1981). Sedangkan unsur P sangat berperan dalam pemasakan biji. Menurut Lingga dan Marsono (2001) unsur $\mathrm{P}$ berperan sebagai bahan mentah untuk pembentukan sejumlah protein tertentu, membantu asimilasi, sekaligus mempercepat pembungaan dan pemasakan biji.

Hal ini dipengaruhi bahwa sifat pelepasan unsur hara yang lambat memberikan pengaruh atau efek yang sedikit. Penggunaan bahan organik akan berdampak jangka panjang. Akumulasi bahan organik dalam tanah yang berasal dari aplikasi jangka panjang bahan organik meningkatkan sifat fisik tanah sawah (Novizan, 2002). Telah lama diketahui bahwa bahan organik tanah memiliki efek menguntungkan pada pertumbuhan tanaman yaitu untuk penambahan nutrisi. Unsur yang berperan dalam pembentukan biji adalah $\mathrm{N}$ dan P.pupuk organik granul padi mampu menyuplai unsur hara $\mathrm{N}$ dan $\mathrm{P}$ ke tanaman akibat adanya proses dekomposisi oleh cacing tanah. Menurut Siregar (1981), bahwa jika tanaman kekurangan unsur $\mathrm{N}$ akan mengakibatkan gabah menjadi hampa. mendekomposisikan bahan organik berupapupuk organik granul padi sehingga unsur hara yang terdapat padapupuk organik granul tersebut mampu lebih cepat diserap oleh tanaman. Penambahan bahan organik berupapupuk organik granul padi ke dalam tanah sehingga terjadi peningkatan efisiensi pemupukan (Adiningsih et al., 2005)

Salah satu penentu keberhasilan dalam suatu usaha budidaya tanaman adalah faktor penggunaan benih yang berasal dari varietas 
unggul (Surowinoto, 1982). Tabel diatas menunjukkan bahwa semakin tinggi perlakuan dosis pupuk organik granul semakin meningkatkan hasil tanaman padi. Peningkatan hasil ini diduga bahwa pupuk organik mampu memperbaiki unsur hara pada tanah yang bisa dimanfaatkan bagi tanaman, sehingga tanaman dapat tumbuh secara optimal. Dengan demikian pemberian pupuk organik mampu meningkatkan hasil dan kualitas padi pada lahan sawah irigasi. Jumlah malai perumpun merupakan indikator untuk melihat jumlah anakan produktif yang menghasilkan jumlah malai perumpun. Malai padi merupakan bagian tanaman yang bersifat generatif berupa sekumpulan bunga padi yang keluar dari buku paling atas (Saragih et al., 2013).

Pemberian pupuk organik 2,0 ton/ha pengaruh yang terbaik dikarenakan peningkatan aktifitas cacing tanah dalam mengubah bahan organik, sehingga menjadi bentuk senyawa lain yang bermanfaat bagi kesuburan tanah. Cacing tanah memakan bahan pupuk organik granul dan menjadikannya partikel-partikel kecil yang selanjutnya dirombak oleh mikroba (Hatta et al., 2010). Hasil dekomposisi dan mikroorganisme disebarkan ke lapisan tanah yang lebih dalam serta meningkatkan aerasi tanah. Cacing tanah yang mati sebagai sumber makanan mikroorganisme tanah dan hara bagi tanaman, sehingga cacing tanah juga berperan meningkatkan jumlah populasi mikroba dan kesuburan tanah. Penambahan bahan organik yang berasal dari sisa tanaman dan kotoran hewan selain menambah bahan organik tanah juga memberikan kontribusi terhadap ketersediaan hara $\mathrm{N}, \mathrm{P}$, dan $\mathrm{K}$ serta mengefisienkan penggunaan pupuk anorganik (Rachman, 2008).

\section{KESIMPULAN DAN SARAN \\ Kesimpulan}

1. Pemberian pupuk organik granul berpengaruh nyata terhadap parameter pertumbuhan tanaman yaitu tinggi tanaman pada umur 60 hari setelah tanam, baik pada padi varitas Mekongga maup un varitas Inpas i 16.

2. Pemberian pupuk organik granul berpengaruh nyata terhadap semua parameter hasil tanaman padi yaitu persentase gabah bernas per malai, bobot 1000 butir gabah dan produksi per hektar baik pada varietas Mekongga maupun varietas Inpari 16.

3. Rata-rata data tertinggi hasil tanaman dijumpai pada pemberian pupuk organik granul 2,0 ton/Ha untuk seluruh parameter yang yang diamati baik pada varietas Mekongga maupun varietas Inpari 16.

4. Rata-rata produksi padi varietas Inpari 16 lebih tinggi sedikit bila dibandingkan dengan produksi padi varietas Mekongga.

\section{Saran}

1. Sehubungan dengan seringnya dijumpai kelangkaan ketersediaan pupuk kimia an-organik seperti Urea, TSP dan $\mathrm{KCl}$ di kios-kios penjualan sarana produksi pertanian, di sarankan kepada petani untuk memilih pupuk organik granul sebagai salah satu alternatif upaya peningkatan produksinya.

2. Dosis pemberian pupuk organik granul yang memberikan hasil tertinggi untuk tanaman padi varietas Mekongga dan Inpari 16 adalah 2,0 ton/ha.

\section{DAFTAR PUSTAKA}

Adiningsih dan Rochayati. 2005. Peranan bahan organik dalam meningkatkan efiisiensi pupuk dan produktivitas tanah. Dalam Jurnal Pengkajian dan Pengembangan Teknologi Pertanian. Balai Besar Pengkajian dan Pengembangan Teknologi Pertanian, Bogor. hlm. 161-181.

Bakhtiar, B.S. Purwoko, Trikoesoemaningtyas, dan I. S. Dewi. 2010. Analisis korelasi dan koefisien lintas antar beberapa 
sifat padi gogo pada media tanah masam. J. Floratek 5 (2) : 86 - 93.

Gardener, Y. Jayasinghe , Y. Tokashiki, M. Kitou \& K. Kinjo.2010. Effect of Synthetic Soil Aggregates as a Soil Ameliorant to Enhance Properties of Problematic Gray (-Jahgaru\|) Soils in Okinawa, Japan. Communications in Soil Science and Plant Analysis, 41(5), 649-664.

Hadisuwito. 2007. Kebijaksanaan dan arah penelitian pupuk dan pemupukan dalam menghadapi tantangan peningkatan produksi tanaman pangan di masa mendatang. Jurnal Litbang Pertanian, XII(1): 1-6.

Harjadi, S.S. 1988. Pengantar Agronomi. Gramedia, Jakarta

Hatta, M., Ichsan dan N.C. Salman. 2010. Respon beberapa varietas padi terhadap waktu pemberian bahan organik pada metode SRI. J.Floratek. 5:43-53.

Lingga, P. dan Marsono. 2001. Petunjuk Penggunaan Pupuk. Penebar Swadaya. Jakarta.

Novizan. 2002. Petunjuk Pemupukan yang Efektif. Agro Medika Pustaka. Jakarta. Samsudin, U. 1982. Dasar-Dasar Penyuluhan dan Modernisasi Pertanian. Binacipta. Bandung.

Ponamperuma, F. A. 1985. Straw asof Plant Nutrients for Wetland Rice. Point 117 - 136 in Organic Matter and

Rice Research. Intstute. Los Banos. Philippines.

Rachman, I.A. 2008. Pengaruh Dosis Bahan Organik dan Pupuk NPK Terhadap Serapan Hara dan Produksi Tanaman Jagung Manis dan Ubi Jalar Di Inceptor Ternate.Tesis. Institut Pertanian Bogor. Bogor
Rao, S, N.S. 2002. Mikroorganisme Tanah dan Pertumbuhan. UI Press.Jakarta. 228-229

Saragih, S.H.Y.,Bayu, E.S., Bangun, M.K. 2013. Karakter Vegetatif dan Generatif Beberapa Varietas Padi Sensitif Aluminium. Jurnal Online Agroekoteknologi, 1 (4): 13741383.

Siregar, H. 1981. Budidaya Tanaman Padi di Indonesia. Sastra Hudaya. Bogor. 318 Hal.

Sitompul, S. M. dan Guritno, B. 1995. Analisis Pertumbuhan Tanaman. UGM Press: Yogjakarta

Suprapto, A., 2002. Land and water resources development in Indonesia dalam FAO Investment in Land and Water. Proceedings of the Regional Consultation.

Surowinoto, S. 1982. Budidaya Tanaman Padi. Jurusan Agronomi Faperta IPB. Bogor. Hal: 56-58.

Tiur. 2009. Keragaman Padi Varietas Indragiri Pada Perbedaan Umur Bibit Dengan Metode SRI (System Of Rice Intensification), Percikan: Vol. 99 Edisi April 2009

Yunizar dan A. Jamil, 2012. Pengaruh sistem tanam dan macam bahan organic terhadap pertumbuhan dan hasil padi sawah di daerah Kuala Cinaku, Kabupaten Indragiri Hulu Riau. 